\title{
切り返しせん定がブドウサンショウ樹の発芽と着果に及ぼす影響
}

\author{
前田隆昭 ${ }^{1} \cdot$ 米本仁巳 ${ }^{2 *} \cdot$ 樋口浩和 ${ }^{3} \cdot$ 北林利樹 $^{4}$ \\ 1 試験研究機構 神内南方系果樹研究所 沖縄分場 900-0021 沖縄県那覇市泉崎 \\ 2 試験研究機構 神内南方系果樹研究所 061-0600 北海道樺戸郡浦臼町 \\ 3 京都大学大学院農学研究科 606-8502 京都市左京区北白川追分町 \\ 4 ありだ農業協同組合６43-0521＼cjkstart和歌山県有田郡有田川町
}

\section{Effects of Cutting Back Pruning on Sprouting and Fruit Set in Japanese Pepper (Zanthoxylum piperitum (L.) DC. f. inerme Makino) Trees}

\author{
Takaaki Maeda $^{1}$, Yoshimi Yonemoto ${ }^{2 *}$, Hirokazu Higuchi ${ }^{3}$ and Toshiki Kitabayashi ${ }^{4}$

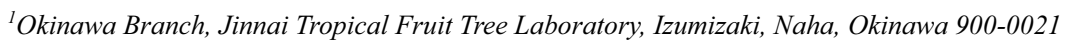 \\ ${ }^{2}$ Jinnai Tropical Fruit Tree Laboratory, Urausu, Kabato, Hokkaido 061-0600 \\ ${ }^{3}$ Graduate School of Agriculture, Kyoto University, Oiwakecho, Kitashirakawa, Sakyo, Kyoto 606-8502 \\ ${ }^{4}$ Arida Agricultural Cooperative, Aridagawa, Arida, Wakayama 643-0521
}

\begin{abstract}
Pruning of Budousanshou (Zanthoxylum piperitum (L.) DC. f. inerme Makino) trees was investigated to determine whether the pruning degree influences sprouting and fruit set. First, the mother branches were divided into three groups by length, and then the four degrees of pruning were set up, i.e. no pruning, cutting back $1 / 3$, cutting back $1 / 2$, and cutting back $2 / 3$ for each mother branch group. The sprouting rate, spike-bearing shoot rate, flower number and berry number in the fruit cluster were compared next spring. As a result, there was a greater tendency toward higher many flower numbers, berry numbers in the fruit cluster and berry numbers per mother branch after cutting back $1 / 3$. These numbers tended to be higher than those in the other pruning groups for the medium mother branch length. The sprouting rate increased when trees were pruned by cutting back $2 / 3$ and the spike-bearing shoot rate tended to become higher after cutting back $1 / 2$ or 2/3.
\end{abstract}

Key Words : berry number, flower number, spike bearing shoot rate, sprouting rate

キーワード : 着花穂新梢率, 発芽率, 果粒数, 花数

\section{緒言}

サンショウ栽培では，枝梢管理方法が確立されていない ため，無せん定で管理される園地の多いことが問題となっ ている，無せん定の園地では，枝が混み合い，収穫や薬剤 散布などの管理作業が困難となる. 内藤（2004）は，サン ショウ樹は隔年結果する習性があり，せん定をしないと収 量の低下を招くばかりでなく，樹の寿命を縮めると報告し ている. また，1998年に和歌山県山村産業試験場が行った 調査では, 無せん定の園地では結果母枝が衰弱し, 弱く短 い新梢が多くなり，また，新梢長は樹勢の指標であり， $5 \mathrm{~cm}$ 以下になると枯死しやい(未発表). しかし，サンショウの せん定に関する研究はきわめて少ない，そこで，本試験で は，切り返しせん定を行い，そのせん定程度が翌年の発芽 や着果に及ぼす影響を検討したので報告する.

2009 年 11 月 13 日 受付. 2010 年 4 月 6 日 受理. 本報告の概要は園芸学会平成 21 年度秋季大会で発表した。

* Corresponding author. E-mail: yonetrop@nifty.com

\section{材料および方法}

和歌山県有田川町の園地に栽植されているフユザンショ ウ (Zanthoxylum alatum Roxb. var. planispinum Rehd. et Wils.) 台の 4 年生ブドウサンショウ (Zanthoxylum piperitum (L.) DC. f. inerme Makino）を用いた. 2007 年 12 月 29 日に，中 庸な生育を示寸水平からやや上向きの結果母枝を 1 樹につ き 12 枝選び，5〜10 cm, $10 \sim 15 \mathrm{~cm}$ および $15 \sim 20 \mathrm{~cm}$ の 3 段階に分けた．結果母枝長ごとに，無せん定，1/3（以 下弱せん定とする），1/2（以下中せん定とする）拈よび $2 / 3$ （以下強せん定とする）に切り返す処理を行った．このよう にして, 各樹 3 水準の結果母枝長に対して各々 4 水準のせ ん定程度区を設けた. 本試験は 6 樹を供試し, 6 反復で行っ た. 結果母枝長扎よび切り返し程度が発芽率, 着花穂新梢 率，花穂当たりの花数および果房当たりの果粒数に及ぼす 影響を検討した.

2008 年 4 月 26 日に, 結果母枝当たりの発芽率と着花穂 新梢率の割合を調査して求めた。発芽率は，結果母枝のす べての芽の中で $3 \mathrm{~mm}$ 以上伸長した芽を発芽とみなし，そ 


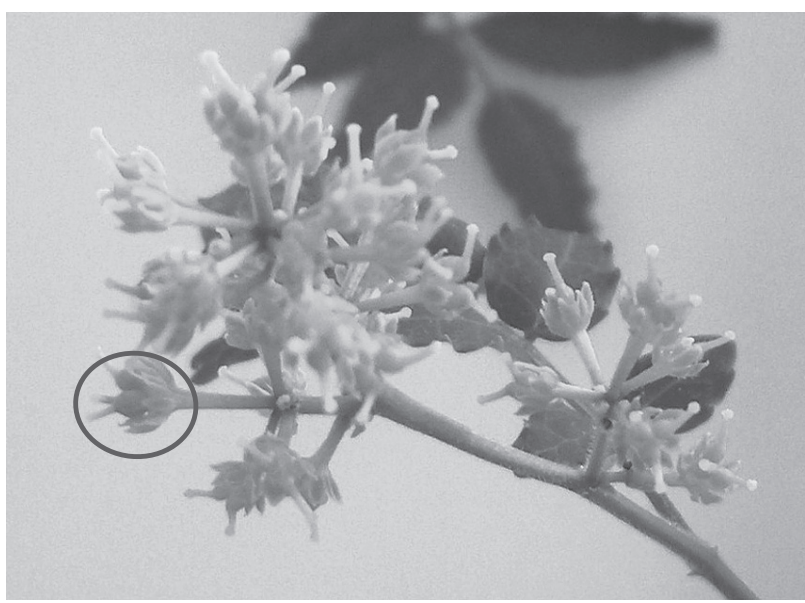

第 1 図 ブドウサンショウの花穂 図中の○印は, 数個の小花をもつ 1 花

の割合を求めた. 着花穂新梢率は, 結果母枝のすべての芽 の中で, 発芽して 1 花でも着花すれば花穂が着生した新梢 とみなし，その割合を求めた。 また，花穂に着生する 2 3 個の小花をもった花を 1 花とし, 花穂当たりの花数を調 査した (第 1 図). これは, 結果母枝の先端から $1 \sim 2$ 花穂 ずつ, 計 20 花穗の調査によって求めた.

2008 年 7 月 20 日に, 果房当たりの果粒数を各処理区で 結果母枝の先端から $1 \sim 2$ 果房ずつ, 計 20 果房調査した. また，結果母枝当たりの総果粒数も調査した.

\section{結果および考察}

発芽率と結果母枝長との間には, 有意な関係は認められな かった (第 2 図). 一方, 切り返しが強いほど発芽率は増加 する傾向であった. ウンシュウミカン (Citrus unshiu Marcow.) でも切り返しせん定の程度が強くなる㭱ど発芽率は高くな り（宮田ら，1997; 末次・夏秋，2000）, ブドウサンショウで も同様の結果となった。

着花穂新梢率と結果母枝長との間にも, 有意な関係は認 められなかった（第 3 図）。切り返し程度が強くなるほど, 着花穂新梢率は高い傾向であった. 特に, 長さが $10 \mathrm{~cm}$ 以 上の結果母枝では，無せん定や弱せん定した場合に比べ, 中〜強せん定により着花穂新梢率が高い傾向であった。

花穂当たりの花数は, 無せん定区以外の処理区で結果母 枝長が $10 \sim 15 \mathrm{~cm}$ の弱せん定区で最も多く, 次いで $15 \sim$ $20 \mathrm{~cm}$ であり, 5 〜 $10 \mathrm{~cm}$ ではすべての処理区で少ない傾向 であった（第 4 図），せん定程度別では, 弱せん定区で多い 傾向であり，特に結果母枝の長さが $10 \sim 15 \mathrm{~cm}$ で 33 個と 最も多く，次いで中せん定区であった。同じミカン科のウ ンシュウミカンでも, 切り返し程度が強くなるほど着花数 は減少している（宮田ら，1997）. ウンシュウミカンは落葉 果樹と異なり, 新梢の発生時に使用される養分の主な貯蔵 場所は葉である（岩垣，2000）ため，その部分をせん定に より失うことは同化産物の減少を招き, 花数の減少につな

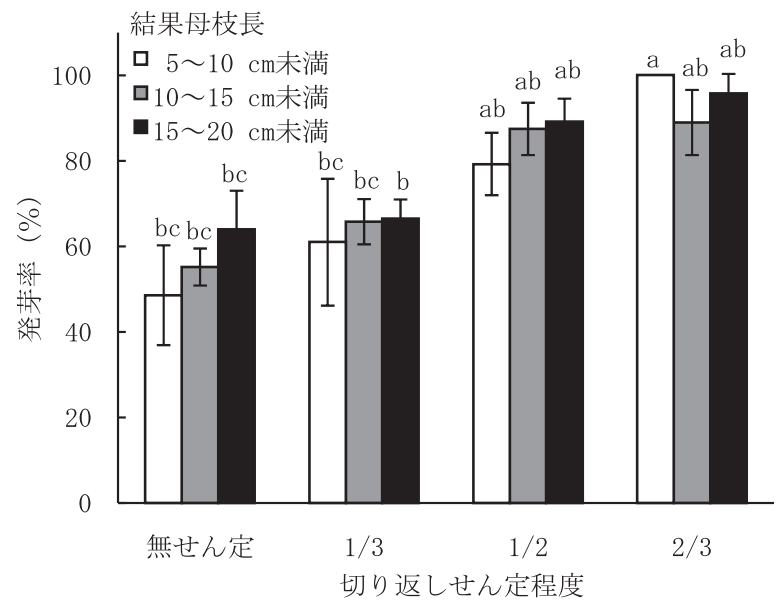

第 2 図結果母枝長拈よびせん定程度の違いがブドウサン ショウの発芽率に及ぼす影響

図中の縦棒は標準誤差を示す $(n=6)$

図中の異なるアルファベット間には $5 \%$ 水準で有意差あ り (Tukey's Test, $\mathrm{n}=6$ )

発芽率は, 結果母枝のすべての芽の中で $3 \mathrm{~mm}$ 以上伸長 した芽を発芽とみなし，その割合で求めた

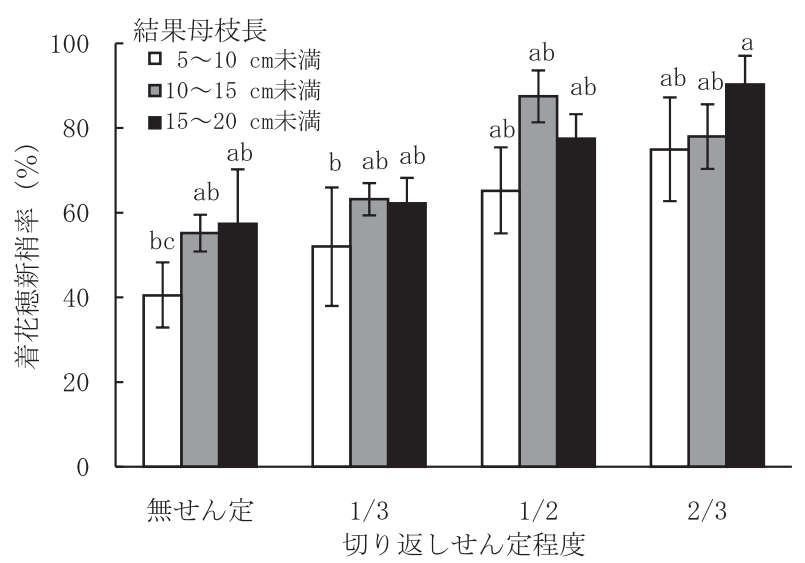

第3 図結果母枝長拈よびせん定程度の違いがブドウサン ショウの着花穂新梢率に及ぼす影響

図中の縦棒は標準䛊差を示す $(\mathrm{n}=6)$

図中の異なるアルファベット間には $5 \%$ 水準で有意差あ り (Tukey's Test, $\mathrm{n}=6$ )

着花穂新梢率は, 結果母枝のすべての芽の中で 1 花でも着 花すれば花穂が着生した新梢とみなし，その割合を求めた

がると考えられた. しかし，ブドウサンショウはカンキッ 近縁属からなるミカン亜科ではなくマツカゼソウ亜科（岩 政，1976）であり，落葉性を示すので花数は休眠枝の貯蔵 養分に影響されると考えられる. 切り返しせん定を行らと 休眠枝中の貯蔵養分の一部を失うことになり，その結果花 数の減少につながると考えてよいかについては, 今後貯蔵 養分と花芽形成の両面から検討する必要がある.

果房当たりの果粒数は，弱せん定区执よび中せん定区で 花穂当たりの花数と同様に結果母枝長が $10 \sim 15 \mathrm{~cm}$ で多 く, 次いで $15 \sim 20 \mathrm{~cm}$ であり, 5〜 $10 \mathrm{~cm}$ の短い結果母枝 では少ない傾向であった（第 5 図），せん定強度別では，弱 


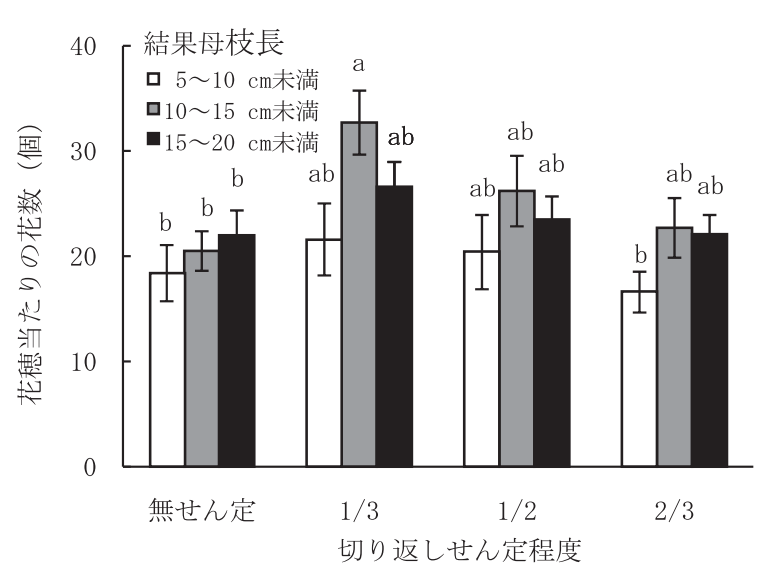

第 4 図結果母枝長およびせん定程度の違いがブドウサン ショウの花穂当たりの花数に及ぼす影響 図中の縦棒は標準詋差を示す $(\mathrm{n}=6)$ 図中の異なるアルファベット間には5\%水準で有意差あ り (Tukey's Test, $\mathrm{n}=6$ )

花穂当たりの花数は, 花穂に着生する $2 \sim 3$ 個の小花を もった花を 1 花として調査

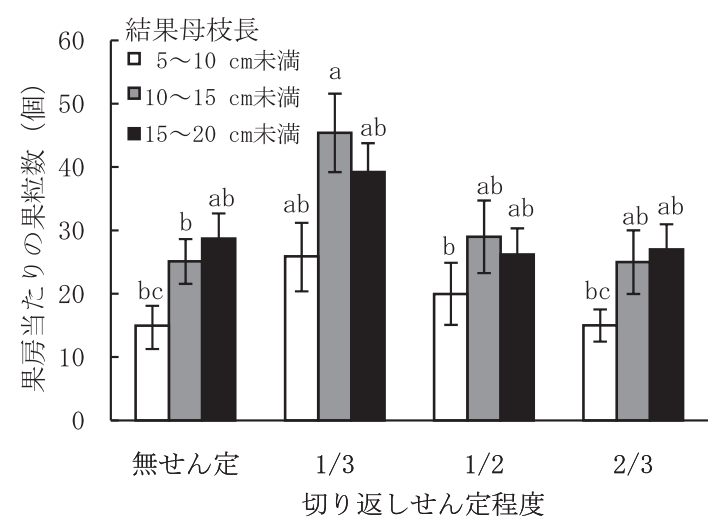

第 5 図結果母枝長拈よびせん定程度の違いがブドウサン ショウの果房当たりの果粒数に及ぼす影響 図中の縦棒は標準詋差を示す $(n=6)$ 図中の異なるアルファベット間には $5 \%$ 水準で有意差あ り (Tukey's test, $\mathrm{n}=6$ )

せん定区の結果母枝長 $10 \sim 15 \mathrm{~cm}$ の果粒数が 45 個と最も 多かった. 2001 年に和歌山県山村産業試験場が行った調査 では, ブドウサンショウの切り返しせん定により栄養成長 が促進される傾向が報告されており (未発表), 養分競合の 結果, 花数が減少し着粒数が減少したと考兄られる. 今後 ブドゥサンショウの貯蔵養分の分配を調査し, 切り返しせ 几定と花数の関連性を解明していく必要があろう.

結果母枝当たりの果粒数は, 結果母枝長別では, 5 $10 \mathrm{~cm}$ が有意に少なかった (第 1 表)。せん定強度別では, 弱せん定区が中せん定区拉よび強せん定区ょり有意に多 かった．ウンシュウミカンでも 20,40 拉よび $60 \%$ と切り 返しせん定を行うと樹冠容積当たりの結実数は $40 \%$ 区が多 く, 最も強くせん定した $60 \%$ 区では有意に少ないことが報 告されている（宮田ら 1997）。2000 年に和歌山県山村産業
第 1 表 結果母枝長扣よびせん定程度の違いがブドウサン ショウの結果母枝当たりの果粒数に及ぼす影響

\begin{tabular}{cccc}
\hline \hline & & $\mathrm{n}$ & $\begin{array}{c}\text { 結果母枝当たり } \\
\text { の果粒数(個) }\end{array}$ \\
\hline & & & $38.3 \mathrm{~b}^{\mathrm{z}}$ \\
結果母枝長 (A) & $10 \sim 10 \mathrm{~cm}$ & 24 & $96.0 \mathrm{a}$ \\
& $15 \sim 20 \mathrm{~cm}$ & 24 & $109.3 \mathrm{a}$ \\
\hline & 無せん定 & 18 & $99.5 \mathrm{ab}$ \\
せん定程度 (B) & $1 / 3$ & 18 & $120.1 \mathrm{a}$ \\
& $1 / 2$ & 18 & $57.1 \mathrm{~b}$ \\
& $2 / 3$ & 18 & $48.1 \mathrm{~b}$ \\
\hline 相互作用 & & &
\end{tabular}

相互作用 $(\mathrm{A}) \times(\mathrm{B}) \quad$ n.s.

$\mathrm{z}$ 異なるアルファベット間には $5 \%$ 水準で有意差あり

(Tukey's Test)

${ }^{\mathrm{y}}$ n.s. は有意差なし

試験場が行った調查では, ブドウサンショウの $2 \sim 3$ 年生 樹に対し，強いせん定を行うと収量が低下し，無せん定で は新梢数が多くなった. 一方, 枝の基部から 10 節程度の切 り返しせん定を行うと，着花数は減少することなく，翌年 の結果母枝となる強い新梢が多く得られたことが報告され ている (未発表).

以上の結果から，弱せん定を行らことで，花穂当たりの 花数, 果房当たりの果粒数, 結果母枝当たりの果粒数を増 加させることが明らかとなった。ただし，発芽率や着花穂 新梢率の割合は，弱せん定区で低くなる傾向があった，せ 几定程度とその後の着果状況を考慮した場合, 結果母枝当 たりの果粒数が多いことが重要となる。 そのためには弱せ 几定を行い，長さ $10 \mathrm{~cm}$ 以上の結果母枝を確保することが 望ましいと考兄られた。しかし，ブドウサンショウの衰弱 の目安となる $5 \mathrm{~cm}$ 以下の結果母枝は間引く必要があろう. また，本試験では実験結果の評価のために樹内で中庸な生 育を示し，水平からやや上向きの結果母枝の久を供試した が，枝の勢いや角度については調査対象を広げてさらに検 討していく必要がある.

\section{摘 要}

ブドウサンショウ樹を切り返しせん定し, 切り返し程度 が翌年の発芽や着果に及ぼす影響を検討した，結果母枝長 によって 3 段階に分け，3段階の各々に対してせん定程度 を無せん定，弱せん定，中せん定拈よび強せん定の 4 区を 設けた．切り返しせん定処理を行った翌年の発芽率，着花 穂新梢率，花数抢よび果房当たり果粒数を比較した。 その 結果, 弱せん定区で花数, 果房当たりの果粒数および結果 母枝当たりの果粒数が多くなった．結果母枝長に関しては 中程度の長さで花数, 果房中果粒数および結果母枝当たり の果粒数が多い傾向を示した，発芽率はせん定程度が強い ほど高くなり，着花穂新梢率は中せん定区および強せん定 区で高い傾向であった. 


\section{引用文献}

岩垣 功. 2000. 整枝・剪定・間伐. p. 329. 果樹園芸大百 科1カンキッ. 農文協. 東京.

岩政正男. 1976. 柑滳の品種. p. 20. 静岡県柑橘農業協同 組合連合会. 静岡.

宮田明義・橋本和光・棟居信一. 1997。 ‘青島温州’ の強制 的隔年結果栽培に関する研究. 第 2 報. せ九定方法が
結果母枝の生育, 果実品質並びに収量に及ぼす影響. 園学雑. 66 (別2)：170-171.

内藤一夫. 2004. サンショウ一実・花・木ノ芽の安定多収 栽培と加工利用一. p. 118 . 農文協. 東京.

末次信行・夏秋道俊. 2000 . 早生温州ミカンに扮ける隔年 交互結実栽培に関する研究. 第 1 報. 地上部管理の方 法打よび収量・品質.九州農業研究. 62: 237. 